garded as the cause of important or adaptive specific change. Therefore, if it is the case that "so many naturalists accept the theory of natural selection as an exclusive explanation of the evolution of existing species," I think that Mr. Dixon has done well to correct their error. Only I am not aware that any naturalist of note has allowed his belief in Darwinism thus to go beyond the teaching of Darwin.

George J. Romanes

\section{Scandinavian Ice-Flows}

FAILING any more direct answer to Sir J. D. Hooker's query (NATURE, vol. xxxiii. p. 79), perhaps, with your usual courtesy, you will allow me space for one or two brief notes. The map referred to, as it stands in "Climate and Time," p. 449, is conjectural to a very large extent. If we are to take the relative closeness of the lines to indicate comparative depth and strength of the glacier-flow, the Baltic must have been, at the intensest period of glaciation, a glacier-filled valley, on an enormous scale, with the ice-stream passing out over the comparatively low, and then submerged, country of Schleswig-Holstein. Dr. Croll, to support a foregone conciusion, represents it thus, and then makes it bifarcate conjecturally about the Dogger Bank. One or two considerations, however, make Dr. Croll's conclusion less "inevitable" than he seems to imagine (p. 449).

(I) Admitting, as we must, that the striations mentioned (p. $44^{8}$ ) on the Island of Bornholm, point to the passage of ice in massive proportions over at least that island in the direction indicated by the lines on the map, we may still call in question the hypothesis which regards the main mass of the Baltic ice as having passed that way.

For (2) the evidence given (p. 449) of its having passed over Denmark (the bare "fact that the surface of the country is strewn with debris derived from the Scandinavian peninsula") is so ambiguous as to be worthless on the point under consideration.

(3) The facts stated by Dr. Croll (stripped of the guise with which he has invested them) can be easily and naturally accounted for by the action of marine ice, owing its origin to the great Scandinavian glaciers of the period; some of which, 'even from the Baltic side, probably drifted away into the present North Sea basin.

But (4) that the main mass of the ice from the eastern slope of the great glaciated Scandinavian range did not take this direction is proved by some of the best-established facts of European geology; facts which, had they been known to Dr. Croll, would have rendered, I venture to think, the construction by him of the map referred to impossible. On p. 447 he says, "After passing down the Baltic, a portion of the ice would probably move south into the flat plains in the north of Germany, but the greater portion would keep in the bed of the Baltic, and of course (sic) turn to the right round the south end of Gothland, and then cross over Denmark into the North Sea."

The naïveté of this statement, in a book bearing date 1875 , is truly refreshing. Any one who knows the district of Jena is perfectly familiar with the enormous abundance of ice-transported material from Scandinavia to be found thereabouts; and these "Findlinge" are spread far and wide over the whole North-German plain as far inland as Bonn, Westphalia, Thüringen, Saxony (even to the south of Zwickau), and, according to Credner's later observations (Sitzber. der naturforsch. Gese' schaft, Leipzig, 1875), into the interior of Bohemia, as far as Troppau, near the sources of the Oder, on the slopes of the Sudeten Gebirge, and even to Toula and Moscow.

(5) Lastly, the occurrence of striated blocks of Scandinavian origin in the boulder-clays of the Yorkshire coast, is clearly incompatible with the conjectural view so graphically expressed on the map in question.

Wellington College, November 30

\section{The Resting Position of the Oyster}

I FEEL some disinclination to take up more space in the pages of NATURE on this subject without making any new contribution to the discussion, but Mr. John A. Ryder's letter induces me to summarise the facts which have been brought forward, and the conclusions to be drawn from them. The condition of the oysters examined by me can only be explained by inferring that they were quite free, and resting on a flat bottom with the right valve downwards. The specimens of
Pecten opercularis which I had before me were in the same condition, and doubtless rested in the same position. Of Pecten maximus I cannot speak with certainty, and therefore leave to Mr. Arthur Hunt the responsibility of stating that there is a difference in respect of position in the two species. Prof. Möbius also finds that the left valves of oysters are usually covered by fixed animals, but as far as I understand his letter he thinks this does not prove that the left valves in this condition were uppermost : in the oysters I examined, the right valves were so clean that they must have been in close contact with the bottom. The other letters on the subject all describe evidence proving that oyster larvæ attach themselves by the lelt valve. This I did not deny, and I might of course easily have found the direct testimony of observers on the subject. $\mathrm{Mr}$. Ryder says it is well known that the right valve of the oyster is always the most deeply pigmented, while the left one is paler in the oysters I examined, the condition of the valves was exactly the reverse of this. It seems to me that when a young oyster is attached to the under-surface of a stone or shell by its left valve its right valve is lower, and if it drops from its attachment, or grows much larger than the stone or shell to which it is fixed, the surface of its right valve will come into close contact with the sea-bottom. I have seen oysters which still retained a piece of shell attached near the umbo of the left valve, while the rest of the valve was covered with fixed animals, and the right valve was quite clean and light in colour. There are no crowded oyster-banks in the Firth of Forth, and it might even be said that the oysters which came under my observation had been dredged and thrown overboard again at some time of their lives. But I do not think oysters are often returned to the water when once taken in the Firth. In my former letter I implied that probably in the normal position of an adult oyster the right valve was in contact with the bottom. That this is often the case when the oyster is free and has plenty of room has not yet been disproved, and therefore I think the current statement that the oyster, when not attached, invariably rests with its left valve downwards needs modification.

Scottish Marine Station, November 28

\section{The Sea-Mills at Argostoli}

I will be glad if, through the columns of your journal, you will be good enough to inform me what has been written in English concerning the phenomenon known as "The Sea-Mills at Argostoli." Having recently visited the island of Cephalonia I was able to examine these mills frequently, and I have reasons for believing that papers have been read at different times at some of the learned societies at home discussing the subject in extenso. I will therefore be glad of any intelligence on this interesting phenomenon which you may be able to refer me to. J. LLOYD THOMAS

H.M.S. Téméraire, Mediterranean, November I 5

\section{Earthquake}

ON Thursday morning, December 3, I was in bed awake, between 6 and 7 o'clock. I heard a slight clattering noise of the earthenware and glass articles on the marble top of the washstand. It lasted for about three seconds, and went with a slight halt near the end. There was no one moving in the house, and nothing outside to cause the tremors, which I did not feel in bed. I immediately got up to look at the clock, and found it was 6.45. I do not know at what time the earthquake in Algeria took place, possibly there was some connection between the two, and the tremor may have been felt in other places in England, so I record this.

Gateshead, December 6

R. S. Newali

\section{VENTILATION}

I $\mathrm{N}$ modern life, with its enormous populations living under artificial conditions in towns and cities, the subject of ventilation, or the supply of sufficient pure air to each individual for the maintenance of health, has assumed, as it has become more generally understood, a vast and national importance. Its importance has been clearly demonstrated in many instances by a greatly diminished death-rate in places where overcrowding on space or in houses, formerly existent, has been remedied, 